Review

\title{
Impact of Abiotic Stresses on Plant Virus Transmission by Aphids
}

\author{
Manuella van Munster
}

INRA, UMR385, CIRAD TA-A54K, Campus International de Baillarguet, CEDEX 05, 34398 Montpellier, France; manuella.van-munster@inra.fr; Tel.: +33(0)4-9962-4857

Received: 16 January 2020; Accepted: 8 February 2020; Published: 14 February 2020

check for updates

\begin{abstract}
Plants regularly encounter abiotic constraints, and plant response to stress has been a focus of research for decades. Given increasing global temperatures and elevated atmospheric $\mathrm{CO}_{2}$ levels and the occurrence of water stress episodes driven by climate change, plant biochemistry, in particular, plant defence responses, may be altered significantly. Environmental factors also have a wider impact, shaping viral transmission processes that rely on a complex set of interactions between, at least, the pathogen, the vector, and the host plant. This review considers how abiotic stresses influence the transmission and spread of plant viruses by aphid vectors, mainly through changes in host physiology status, and summarizes the latest findings in this research field. The direct effects of climate change and severe weather events that impact the feeding behaviour of insect vectors as well as the major traits (e.g., within-host accumulation, disease severity and transmission) of viral plant pathogens are discussed. Finally, the intrinsic capacity of viruses to react to environmental cues in planta and how this may influence viral transmission efficiency is summarized. The clear interaction between biotic (virus) and abiotic stresses is a risk that must be accounted for when modelling virus epidemiology under scenarios of climate change.
\end{abstract}

Keywords: Plant virus; abiotic stress; insect; vector transmission; drought; temperature; $\mathrm{CO}_{2}$; viral accumulation; aphid

\section{Introduction}

Transmission is a key step in the life cycle of a virus, allowing viral maintenance in an ecosystem. Most plant viruses rely on a third party for host-host spread, with sap-sucking insects from the order Hemiptera (aphids, whiteflies, planthoppers, and leafhoppers) being by far the most widespread vectors $[1,2]$. Thus, virus transmission during the feeding process relies on a complex set of interactions that are the result of the co-evolution of at least three partners: the pathogen, the vector, and the host plant-each with its own behaviour, population, and community dynamics [3-5].

The feeding process is best described for aphids, but the same basic principles also apply to other species of the orders Hemiptera or Thysanoptera. Insect feeding can be monitored by the Electrical Penetration Graph (EPG) technique, which provides live visualization and recording of plant penetration by insect mouthparts [6,7]. Non-circulative transmission-in which the virus taken up by a vector on an infected plant attaches to the inner part of the cuticle lining of the feeding apparatus [8] and is subsequently released and inoculated into a new host plant-is the predominant strategy for plant virus-vector interactions. All three steps-acquisition, retention, and inoculation-generally occur within seconds to minutes and do not require passage within the vector's body. In this system, viruses are acquired mainly during probing and transient puncturing of epidermal and mesophyll cells of infected leaf tissues (see [9] for review). The second category of viral transmission is designated circulative non-propagative transmission and is characterised by longer acquisition and inoculation periods (from hours to days), and long retention time in the vector body that can last several weeks, 
and often until the vector dies. In that case, the virus crosses the gut epithelium of the insect vector, diffuses into the haemolymph, and reaches and accumulates into the salivary glands without replicating. Finally, in the third category, designated circulative and propagative transmission, the virus completes a similar cycle within the vector's body but replicates within the gut, the salivary glands, and sometimes other tissues of the insect before inoculation into a new host plant. These two latter modes of transmission are found mainly for phloem-limited viruses that are acquired and inoculated by insect vectors during long-lasting sap ingestion phases in sieve tubes (see [9] for review).

Many studies have provided evidence that viruses themselves might alter specific aspects of host plant phenotypes and/or vector behaviour in ways that enhance their transmission, also described as the "Vector Manipulation Hypothesis" [10-14]. Thus, plant viruses can modulate the amino acid composition of host sap [15,16]; plant defence pathways and their associated molecular signalling [17,18]; release of attractive volatiles [19-21]; and enhancement of yellowing disease symptoms on foliage [22,23], potentially favouring or disabling insect attraction, growth and reproduction, and finally colonisation of the host plant $[17,24,25]$. It is noted that in some cases, neutral effects of the virus infection on vector behaviour and performance might also be part of the adaptative strategy of the pathogen (see for review [13]).

Interestingly, convincing evidence that plant-insect interplay adapts in such a way that virus-induced changes in vector behaviour specifically match the viral mode of transmission has emerged from these studies (reviewed in [26,27]). Briefly, a virus transmitted in a circulative (either propagative or not) way should attract and arrest insect vectors, favouring settlement, reproduction, colony formation, and perhaps late production of "migrators"' to ensure maximum dissemination. A non-circulative transmitted virus, in contrast, should have no effect, or should attract but then repel vectors, because its acquisition is fast and retention time extremely short [28-30].

\section{Impact of Abiotic Stresses on Viral Transmission}

Interactions between plants, viruses, and vectors are affected greatly by environmental conditions, ultimately shaping the spread of viral diseases (see [31] for review). Ongoing climate change is raising the frequency, intensity, and duration of abiotic stresses on plants, and climate prediction is pessimistic [32]. Among these changes, elevated temperatures, increased $\mathrm{CO}_{2}$ and $\mathrm{O}_{3}$ levels, and altered precipitation patterns are major stresses impacting plant performance, population dynamics, and ecology [33-36]. Under such conditions, and similarly to what happens upon virus infection, physiological changes in host plant status are also accompanied at the biochemical level by modification of sap composition, as well as alteration of phytohormones levels and signalling pathways [37, 38], which may thus impact multiple plant virus transmission parameters (see $[39,40]$ for review), as discussed below.

Temperature fluctuations have long been studied as a key environmental climate parameter shaping viral disease epidemiology [41-43]. The luteovirus Potato leafroll virus (PLRV) was shown to be better transmitted by Myzus persicae to Physalis floridana when it was both acquired and inoculated at a higher temperature $\left(26^{\circ} \mathrm{C}\right.$ vs. $\left.12{ }^{\circ} \mathrm{C}\right)$ [44]. This result is linked to previous work showing that a higher temperature reduces the latent period of PLRV within the vector, increasing the speed with which the virus moves from the gut to the salivary system via the hemolymph [45]. The optimum temperature corresponding to efficient disease development within the host in relation to the vector's biology and transmission process (i.e., acquisition, latency, and inoculation phases) has been determined in several pathosystems. Studies on the transmission efficiency of Banana bunchy top virus by the aphid Pentalonia nigronervosa shows that both acquisition and inoculation of the virus are optimal at $25{ }^{\circ} \mathrm{C}$. Temperature has a similar effect on the biology of $P$. nigronervosa with enhancement of vector fecundity at this temperature, suggesting that biological factors, such as aphid feeding behaviour, may have been of importance in determining the transmission rates [46]. It has been noted that the optimum temperature for plant virus transmission is pathosystem-dependent, and might differ slightly depending on the transmission step considered [47]. While the two potyviruses Potato virus A (PVA) and Potato virus $Y$ 
(PVY) and PLRV are better transmitted, when acquisition by M. persicae is realised at $20^{\circ} \mathrm{C}$, the optimal temperature for further establishment of the infection differs according to virus species [48]. Optimal infection of PVA- or PVY- inoculated N. benthamiana occurs at $20^{\circ} \mathrm{C}$, while a temperature of $25^{\circ} \mathrm{C}$ allows for the best disease development in PLRV-inoculated P. floridana [48].

Several studies have also focused on analyzing viral transmission efficiency under a combination of abiotic stresses including temperature [49-51]. In their study, Singh and colleagues looked at the inoculation step of PVY and PLRV under different conditions of temperature, relative humidity (RH), and light. While light intensity did not seem to affect virus infection, high temperature $\left(25-30^{\circ} \mathrm{C}\right)$ and high RH (80-90\%) increased transmission of both viruses by $30-35 \%$ [49]. Smyrnioudis and colleagues [50] highlight the role of the vector in the spread of the luteovirus Barley yellow dwarf virus (BYDV) under condition of drought and variable temperature. The positive effect of elevated temperature on aphid movement is exacerbated by the combination of drought and high temperature, significantly increasing BYDV transmission efficiency [50].

In recent years, there have been some reports on the effects of other abiotic factors, namely $\mathrm{CO}_{2}$, $\mathrm{O}_{3}$, and water stress, on the spread of viral diseases as a consequence of the extreme environmental changes [48,51-58]. Dader and colleagues [53] thoroughly examined the impact of elevated $\mathrm{CO}_{2}$ levels $\left(\mathrm{eCO}_{2}\right)$ on M. persicae life history, feeding behaviour, and the virus transmission ability of Cucumber mosaic virus (CMV; cucumovirus) to pepper plants (Capsicum annuum), transmitted in a non-circulative manner. Potential effects of $\mathrm{eCO}_{2}$ on virus transmission and acquisition efficiency were evaluated under two $\mathrm{CO}_{2}$ regimes with several application timings. When both infected source plants and receptor plants had grown under $\mathrm{eCO}_{2}$ prior to transmission experiments, a two-fold decrease in CMV transmission was observed. The reason evoked to explain this decrease was the settlement of plant resistance mechanisms under $\mathrm{eCO}_{2}$ during virus inoculation rather than alterations in feeding behaviour of the vector. Indeed, EPG experiments did not reveal any differences in the number of stylet punctures that could have explained this alteration in transmission levels [53]. However, different results were obtained in PVY transmission experiments realised under similar conditions. When PVY-infected tobacco plants and M. persicae aphids were placed under $\mathrm{eCO}_{2}$ levels $(800 \mathrm{ppm}$ vs. $450 \mathrm{ppm}$ ), transmission efficiency increased [59]; however, no clear explanation for this increase was apparent.

The dramatic influence of a water deficit applied to Brassica rapa infected source plants on the transmission efficiency of two unrelated virus species (Cauliflower mosaic virus; CaMV; caulimovirus and Turnip mosaic virus; TuMV; potyvirus), transmitted in a non-circulative way by M. persicae, was reported [54]. In this latter study, alteration of the transmission process during the acquisition phase was assessed directly, and neither the aphids nor the receptor plants were submitted to any particular stress. Thus, the only parameter tested was the impact of drought on CaMV- or TuMV-infected B. rapa plants and the efficacy of virus acquisition depending on the water status of the infected plants. Under these conditions, a severe water deficit applied to CaMV- or TuMV-infected plants dramatically enhanced transmission by around $34 \%$ and $100 \%$, respectively, without any change in within-host viral accumulation [54]. Although feeding behaviour was not analysed thoroughly by EPG monitoring, no distinct aphid behaviour that could explain the alteration in the transmission rate that was observed during the $2 \mathrm{~min}$ of feeding acquisition [54]. As discussed in the conclusions of this review, other factors linked to the intrinsic capacity of these two specific viruses to respond to changes in the physiological status of the host plant may be responsible for the observed increased transmission. Interestingly, transmission of Soybean mosaic virus (SMV), another potyvirus, was not impacted in a similar way by water deficit [57]. In that case, SMV transmission was reduced in soybean (Glycine max L.) plants under water deficit, while it increased significantly in a saturated water regime. It should be noted that in this latter report, both infected source plants, receptor plants, and vector populations were subjected to an identical water regime. Specific changes were observed in abscisic acid, salicylic acid, and jasmonic acid signalling according to the water stress condition (deficit vs. saturated) which may partly explain the impact on virus transmission and virus infection development [57]. 


\section{Vector Feeding Behaviour under Abiotic Stresses}

Several aspects of a vector's life history (e.g., developmental time, longevity, fecundity, feeding habits, geographic distribution) are affected by climate change [60-63] and there have been recent attempts to predict long-term effects on insect dynamics [64,65]. In particular, it is well known that aphid vectors react strongly to small changes in temperature or $\mathrm{eCO}_{2}$ due to their short generation times and great capacity for reproduction [66].

In particular, as evoked in the previous section, abiotic stresses may affect the feeding behaviour and fitness of sap-sucking insects through changes in plant physiology, alteration of host plant quality (i.e., secondary metabolites, essential amino acids, carbohydrates pools, etc.), and activation of plant defences [67-69], with potential consequences for virus transmission efficiency [53,54,56]. Some aphid species are reported to have a greater reproductive capacity under drought conditions than under non-drought conditions [70]. The most accepted explanation for this phenomenon was proposed by White and colleagues [71] in their study on psyllids—closely related to aphids—who suggested that drought increases the hydroxylation of proteins, which subsequently increases the levels of free amino acids available. Analysis of aphid feeding behaviour also indicates that drought stress increases mesophyll/phloem resistance [72], plausibly due to changes in phloem sap viscosity as a result of altered sugar and solute concentrations, making it harder for aphids to acquire nutrients [73]. Changes in the water potential of the host plant due to water stress can also increase the aphids' ability to consume xylem sap, allowing aphids to deal with high sugar concentrations and osmotic pressure of the phloem sap [72,74]. EPG experiments conducted on Aphis glycines showed that feeding behaviour is significantly altered by different water stress regimes [57]. Aphids showed a significantly greater number of stylet punctures when reared on soybean plants grown under a saturated water regime compared to a drought treatment. In terms of behaviour critical for non-circulative transmission, this feature could explain the higher transmission rate of SMV reported in this study [57]. Interestingly, the authors also showed that irrespective of the water stress treatment, non viruliferous aphids show a greater number of stylet punctures compared to viruliferous aphids, highlighting the influence of the virus on the feeding behaviour and thus on the outcome of the infection. In another study, when a water deficit was applied to Arabidopsis thaliana (Col-0) infected with Turnip yellows virus (TuYV), a phloem-restricted luteovirus, transmission efficiency was reduced by $50 \%$, most probably through alteration of feeding behaviour of the vector [55]. Indeed, while TuYV within-host accumulation was not altered by drought, virus load was reduced drastically in $M$. persicae vectors feeding on water-stressed TuYV-infected $A$. thaliana plants [55]. This result suggests an increase of aphid feeding from xylem vessels to balance the osmotic pressure of the sugar-rich phloem sap and avoid dehydration [75,76].

Several studies have considered the vectors life's history during the tripartite interaction virus-vector-host plant under $\mathrm{eCO}_{2}[53,77,78]$. As generally reported, the $\mathrm{eCO}_{2}$ concentration broadly affects plant physiology in both a positive and a negative manner. Positive effects of $\mathrm{eCO}_{2}$ include increased plant height and aboveground biomass, increased rates of photosynthesis, greater light use efficiency, and higher water-use efficiency due to the partial closure of stomata [79-81]. However, $\mathrm{eCO}_{2}$ can cause serious changes to plant biochemistry, including an increase in the carbon $(\mathrm{C})$ to nitrogen $(\mathrm{N})$ ratio caused by a reduction in foliar $\mathrm{N}$ and an increase in $\mathrm{C}$ due to higher growth and photosynthetic rates [80]. Although overall trends among insects reared on plants exposed to $\mathrm{eCO}_{2}$ show either a negative effect on population growth or increased feeding rates to compensate for lower $\mathrm{N}$ content $[82,83]$, aphids are one of the few examples where $\mathrm{eCO}_{2}$ can increase population abundance, but this is often species and host specific [84]. Concerning aphid feeding behaviour, decreased salivation into sieve elements, increased phloem sap ingestion and a reduction of penetration attempts are among the responses observed for Acyrthosiphon pisum on Medicago truncatula, and M. persicae on pepper plants under $\mathrm{eCO}_{2}$ to maintain the quality of ingested nutrients $[53,63]$. The same feeding behaviour pattern was observed for Rhopalosiphum padi feeding on noninfected wheat plants grown under $\mathrm{eCO}_{2}$, with a $34 \%$ increase in the duration of phloem ingestion compared with plants grown under normal conditions [77]. It is believed that the objective of this altered feeding behaviour is to compensate 
for the significant decrease in $\mathrm{N}$ content in plants growing under $\mathrm{eCO}_{2}$. More surprisingly, $\mathrm{BYDV}$ infection is able to mediate the effects of $\mathrm{eCO}_{2}$ on wheat by partially restoring $\mathrm{N}$ content, consequently re-establishing vector performance and feeding behaviour [77].

\section{Alteration of Viral Traits under Abiotic Stresses}

The perturbating effects of abiotic stresses on host physiological status might also influence the life cycle of viruses and the relationships between viral traits such as within-host accumulation and disease severity (or virulence), introducing the possibility of an additional layer of complexity that may have an impact on virus transmission itself $[39,40,85]$.

Plant signalling pathways and responses to various abiotic stresses are partly shared with those induced by viral infection, and the fact that they can interfere with one another is not a novel concept (see [86] and references therein). The effect of abiotic/biotic plant stresses on viral accumulation through the hijacking of plant signalling and defence pathways has received much recent attention [86-89]. Plant abiotic stress sensing, likely through the $\mathrm{Ca}^{2+}$ signalling pathway, was shown for the potyvirus PVA [86]. When PVA-infected N. benthamiana leaves were subjected to salt, osmotic, or wounding stress, the PVA gene expression increased, probably due to an elevation in cytosolic $\mathrm{Ca}^{2+}$ concentration. Similarly, BYDV, one of the most widely distributed viral diseases of cereals, significantly increases its titre by more than $30 \%$ in wheat growing under $\mathrm{eCO}_{2}$ or elevated temperature $[87,90]$.

However, this positive effect of $\mathrm{eCO}_{2}$ concentration on virus accumulation cannot be generalized. In other pathosystems, namely Tomato yellow leaf curl virus (TYLCV), a geminivirus transmitted by the whitefly Bemisia tabacci/Solanum lycopersicum (tomato) and PVY/Nicotiana tabacum (tobacco), virus accumulation decreased significantly under $\mathrm{eCO}_{2}$ levels [91-93]. In both these latter cases, this observation was correlated with a decrease in disease severity due to the modulation of phytohormones by eCO 2 levels. In PVY, a combination of elevated temperature and $\mathrm{CO}_{2}$ levels [i.e., $30^{\circ} \mathrm{C}$ and 970 parts-per-million (ppm), respectively] decreased viral titres in N. benthamiana plants drastically compared with standard conditions $\left(25^{\circ} \mathrm{C}, \sim 405 \mathrm{ppm} \mathrm{CO}_{2}\right)$, ultimately reducing the probability of transmission by M. persicae [51]. In the case of SMV, accumulation was reduced in soybean plants experiencing a severe water deficit, while viral infection increased significantly under water-saturated conditions [57]. Similarly, CaMV accumulation was reduced in several A. thaliana accessions subjected to water deficit [52]. Moreover, under these conditions, disease appearance and development were negatively affected, likely due to a slower systemic movement and the long-distance transport of viral particles through phloem [52,94].

Several factors, such as more efficient RNA silencing-mediated plant defence, may explain the lower incidence of virus disease under abiotic stress [95-97]. Chung and colleagues [98] examined the effects of various temperatures on TuMV symptom intensity and the speed of systemic infection in B. campestris. Plants mechanically inoculated with TuMV and subjected to a temperature gradient (from $13^{\circ}$ to $33^{\circ} \mathrm{C}$ ) showed a complete loss of viral symptoms associated with lower virus accumulation at higher temperatures. The authors assumed that the higher temperature prohibited virus replication and movement due to the activation of plant defence mechanisms [85,99]. Similarly, viral accumulation of the cucumovirus Peanut stunt virus showed a rapid increase at the beginning of the infection at a higher temperature $\left(27^{\circ} \mathrm{C}\right.$ vs. $\left.21^{\circ} \mathrm{C}\right)$, followed by a dramatic decrease in $N$. benthamiana plants due to the induction of plant defences [100].

However, it seems that the strength of antiviral silencing at a high temperature, or those of the viral suppressors that counteract it, may not be the only determinant, and is pathosystem specific [101]. $\mathrm{CMV}$ accumulation within $N$. benthamiana was not affected when plants were grown at $30^{\circ} \mathrm{C}$, while PVY accumulation was strongly reduced by $50 \%$ compared with standard growing conditions $\left(25^{\circ} \mathrm{C}\right)$ [101]. Interestingly, P23, a viral suppressor of RNA silencing of the crinivirus Lettuce chlorosis virus, induced local necrosis in N. benthamiana plants with increased severity at raised temperatures [102]. This observation is intriguing since it is generally reported that an increase in necrosis severity is enhanced at lower temperatures for viruses with a known efficient RNA silencing suppressor $[95,103,104]$. 


\section{Conclusions}

Changes to plant distribution, growth rates, plant physiological status, and biochemistry mediated by future climates are likely to have a major impact on insect vector biology, feeding behaviour and, ultimately, the spread of viral disease. The unequivocal conclusion is that abiotic stresses (e.g., temperature, $\mathrm{CO}_{2}, \mathrm{O}_{3}$, water stress) can have a dramatic effect on viral transmission rates $[48,53-55,57]$.

In particular, there is direct evidence that infected plants subjected to drought can facilitate viral transmission and that this effect is independent of other putative factors such as the attraction of vectors and modification of their fitness [54]. Although the underlying mechanisms remain elusive at this stage, it has been suggested that the dramatic increases in CaMV and TuMV transmission rate are due to changes in the host plant physiological status that could trigger a direct effect on virus behaviour [105]. To date, this new concept, called "perceptive viral behaviour", has been shown for a few plant viruses transmitted non-persistently, namely CaMV, TuMV and PVY, and describes the notion that viruses can "sense" aphid feeding activity, as well as some abiotic stresses, and immediately and reversibly produce transmissible morphs or provoke a viral cellular relocalization [106-108]. Such rapid viral reaction actually predisposes the infected plant to more efficient virus acquisition and transmission by aphid vectors. This remarkable phenomenon has been designated "transmission activation" and it can be triggered by abiotic stresses such as $\mathrm{CO}_{2}$ treatments [109].

Moreover, while beyond the scope of the present review-although it highlights the entanglement of plant-virus interactions-is the observation of the protective effect of virus infection on plant responses to abiotic stresses. This phenomenon has been observed for several viruses (CMV, Brome mosaic virus, TMV, Tobacco rattle virus, CaMV and TuMV) and a large panel of host plants, including rice (Oryza sativa), beet (Beta vulgaris), tobacco, N. benthamiana, tomato, Solanum habrochaities, pepper, watermelon (Cucumis lanatus), cucumber (Cucumis sativus), zucchini squash (Cucurbita pepo), Chenopodium amaranticolor, A. thaliana, barley (Hordeum vulgare) and B. rapa [54,110-112]. These findings suggest that host responses to virus infection that engender drought or cold resistance, such as alterations in small RNA pathways, responses to abscisic acid, changes in the metabolism of osmoprotective compounds, or effects on salicylic acid-mediated signalling are widely conserved [110-113]. They also support the concept that viruses can, at least under certain conditions, act as mutualistic symbionts [114].

Together with the consistent observation that several virus species react to environmental changes in ways that lead to an increase in transmission, a situation where infected plants can better survive adverse environmental conditions and are better sources for viral transmission, invite further investigation. Indeed, a clear interaction between biotic (virus) and abiotic stresses is seen as a risk that must be accounted for when modelling virus epidemiology under scenarios of climate change.

Funding: This research received no external funding.

Acknowledgments: I am very grateful to Helen Rothnie for critical reading and editing of the manuscript.

Conflicts of Interest: The author declares no conflict of interest.

\section{References}

1. Bragard, C.; Caciagli, P.; Lemaire, O.; Lopez-Moya, J.J.; MacFarlane, S.; Peters, D.; Susi, P.; Torrance, L. Status and prospects of plant virus control through interference with vector transmission. Annu. Rev. Phytopathol. 2013, 51, 177-201. [CrossRef] [PubMed]

2. Hogenhout, S.A.; Ammar el, D.; Whitfield, A.E.; Redinbaugh, M.G. Insect vector interactions with persistently transmitted viruses. Annu. Rev. Phytopathol. 2008, 46, 327-359. [CrossRef] [PubMed]

3. Clark, R.E.; Basu, S.; Lee, B.W.; Crowder, D.W. Tri-trophic interactions mediate the spread of a vector-borne plant pathogen. Ecology 2019, 100, e02879. [CrossRef] [PubMed]

4. Mauck, K.E. Variation in virus effects on host plant phenotypes and insect vector behavior: What can it teach us about virus evolution? Curr. Opin. Virol. 2016, 21, 114-123. [CrossRef] 
5. Simon, J.C.; Biere, A.; Sugio, A. The promises and challenges of research on plant-insect-microbe interactions. Insect Sci. 2017, 24, 904-909. [CrossRef]

6. Tjallingii, W.F.; Hogen Esch, T. Fine structure of aphid stylet routes in plant tissues in correlation with EPG signals. Physiol. Entomol. 1993, 18, 317-328. [CrossRef]

7. Fereres, A.; Moreno, A. Behavioural aspects influencing plant virus transmission by homopteran insects. Virus Res. 2009, 141, 158-168. [CrossRef]

8. Uzest, M.; Gargani, D.; Drucker, M.; Hebrard, E.; Garzo, E.; Candresse, T.; Fereres, A.; Blanc, S. A protein key to plant virus transmission at the tip of the insect vector stylet. Proc. Natl. Acad. Sci. USA 2007, 104, 17959-17964. [CrossRef]

9. Whitfield, A.E.; Falk, B.W.; Rotenberg, D. Insect vector-mediated transmission of plant viruses. Virology 2015, 479-480, 278-289. [CrossRef]

10. Ingwell, L.L.; Eigenbrode, S.D.; Bosque-Pérez, N.A. Plant viruses alter insect behavior to enhance their spread. Sci. Rep. 2012, 2, 578-615. [CrossRef]

11. Moreno-Delafuente, A.; Garzo, E.; Moreno, A.; Fereres, A. A plant virus manipulates the behavior of its whitefly vector to enhance its transmission efficiency and spread. PLoS ONE 2013, 8, e61543. [CrossRef] [PubMed]

12. Shoemaker, L.G.; Hayhurst, E.; Weiss-Lehman, C.P.; Strauss, A.T.; Porath-Krause, A.; Borer, E.T.; Seabloom, E.W.; Shaw, A.K. Pathogens manipulate the preference of vectors, slowing disease spread in a multi-host system. Ecol. Lett. 2019, 22, 1115-1125. [CrossRef] [PubMed]

13. Mauck, K.E.; Chesnais, Q.; Shapiro, L.R. Evolutionary Determinants of Host and Vector Manipulation by Plant Viruses. Adv. Virus Res. 2018, 101, 189-250. [PubMed]

14. Mauck, K.E.; Kenney, J.; Chesnais, Q. Progress and challenges in identifying molecular mechanisms underlying host and vector manipulation by plant viruses. Curr. Opin. Insect Sci. 2019, 33, 7-18. [CrossRef]

15. Mauck, K.E.; De Moraes, C.M.; Mescher, M.C. Effects of Cucumber mosaic virus infection on vector and non-vector herbivores of squash. Commun. Integr. Biol. 2010, 3, 579-582. [CrossRef]

16. Mauck, K.; De Moraes, C.; Mescher, M. Cucumber mosaic virus-induced changes in volatile production and plant quality: Implications for disease transmission and multitrophic interactions. Phytopathology 2014, 104, S3.151.

17. Wu, D.; Qi, T.; Li, W.X.; Tian, H.; Gao, H.; Wang, J.; Ge, J.; Yao, R.; Ren, C.; Wang, X.B.; et al. Viral effector protein manipulates host hormone signaling to attract insect vectors. Cell Res. 2017, 27, 402-415. [CrossRef]

18. Guo, H.; Gu, L.; Liu, F.; Chen, F.; Ge, F.; Sun, Y. Aphid-borne Viral Spread Is Enhanced by Virus-induced Accumulation of Plant Reactive Oxygen Species. Plant Physiol. 2019, 179, 143-155. [CrossRef]

19. Medina-Ortega, K.J.; Bosque-Perez, N.A.; Ngumbi, E.; Jimenez-Martinez, E.S.; Eigenbrode, S.D. Rhopalosiphum padi (Hemiptera: Aphididae) responses to volatile cues from Barley yellow dwarf virus-infected wheat. Environ. Entomol. 2009, 38, 836-845. [CrossRef]

20. Eigenbrode, S.D.; Ding, H.; Shiel, P.; Berger, P.H. Volatiles from potato plants infected with Potato leafroll virus attract and arrest the virus vector, Myzus persicae (Homoptera, Aphididae). Proc. R. Soc. Lond. B 2002, 269, 455-460. [CrossRef]

21. Claudel, P.; Chesnais, Q.; Fouche, Q.; Krieger, C.; Halter, D.; Bogaert, F.; Meyer, S.; Boissinot, S.; Hugueney, P.; Ziegler-Graff, V.; et al. The Aphid-Transmitted Turnip yellows virus Differentially Affects Volatiles Emission and Subsequent Vector Behavior in Two Brassicaceae Plants. Int. J. Mol. Sci. 2018, 19, 2316. [CrossRef] [PubMed]

22. Robert, Y. Aphids and their environment. In Aphids their Biology, Natural Enemies, and Control; Minks, A.K., Harrewijn, P., Eds.; Elsevier: Amsterdam, The Netherlands, 1987; Volume 2A, pp. 299-313.

23. Fereres, A.; Kampmeier, G.E.; Irwin, M.E. Aphid attraction and preference for soybean and pepper plants infected with potyviridae. Ann. Entomol. Soc. Am. 1999, 92, 542-548. [CrossRef]

24. Carmo-Sousa, M.; Moreno, A.; Garzo, E.; Fereres, A. A non-persistently transmitted-virus induces a pull-push strategy in its aphid vector to optimize transmission and spread. Virus Res. 2014, 186, 38-46. [CrossRef] [PubMed]

25. Li, R.; Weldegergis, B.T.; Li, J.; Jung, C.; Qu, J.; Sun, Y.; Qian, H.; Tee, C.; van Loon, J.J.; Dicke, M.; et al. Virulence factors of geminivirus interact with MYC2 to subvert plant resistance and promote vector performance. Plant Cell 2014, 26, 4991-5008. [CrossRef] [PubMed] 
26. Stafford, C.A.; Walker, G.P.; Ullman, D.E. Hitching a ride: Vector feeding and virus transmission. Commun. Integr. Biol. 2012, 5, 43-49. [CrossRef]

27. Mauck, K.; Bosque-Pérez, N.A.; Eigenbrode, S.D.; De Moraes, C.M.; Mescher, M.C.; Fox, C. Transmission mechanisms shape pathogen effects on host-vector interactions: Evidence from plant viruses. Funct. Ecol. 2012, 26, 1162-1175. [CrossRef]

28. Rajabaskar, D.; Bosque-Perez, N.A.; Eigenbrode, S.D. Preference by a virus vector for infected plants is reversed after virus acquisition. Virus Res. 2014, 186, 32-37. [CrossRef]

29. Bosque-Perez, N.A.; Eigenbrode, S.D. The influence of virus-induced changes in plants on aphid vectors: Insights from luteovirus pathosystems. Virus Res. 2011, 159, 201-205. [CrossRef]

30. Stafford, C.A.; Walker, G.P.; Ullman, D.E. Infection with a plant virus modifies vector feeding behavior. Proc. Natl. Acad. Sci. USA 2011, 108, 9350-9355. [CrossRef]

31. Harrison, B.D. Plant virus ecology: Ingredients, interactions and environmental influences. Ann. Appl. Biol. 1981, 99, 195-209. [CrossRef]

32. Field, C.B.; Barros, V.R.; Mastrandrea, M.D.; Mach, K.J.; Abdrabo, M.A.-K.; Adger, W.N.; Anokhin, Y.U.; Anisimov, O.A.; Arent, D.J.; Barnett, J.; et al. Summary for Policy Makers: Working Group 11 Contribution to the Fifth Assessment Report of the Intergovernmental Panel on Climate Change; (Climate Change 2014: Impacts, Adaptation and Vulnerability-Contributions of the Working Group II to the Fifth Assessment Report); Cambridge University Press: Cambridge, UK, 2014.

33. Farooq, M.; Wahid, A.; Kobayashi, N.; Fujita, D.; Basra, S.M.A. Plant drought stress: Effects, mechanisms and management. Agron. Sustain. Dev. 2009, 29, 185-212. [CrossRef]

34. Myers, S.S.; Zanobetti, A.; Kloog, I.; Huybers, P.; Leakey, A.D.; Bloom, A.J.; Carlisle, E.; Dietterich, L.H.; Fitzgerald, G.; Hasegawa, T.; et al. Increasing $\mathrm{CO}_{2}$ threatens human nutrition. Nature 2014, 510, 139-142. [CrossRef] [PubMed]

35. Des Marais, D.L.; Lasky, J.R.; Verslues, P.E.; Chang, T.Z.; Juenger, T.E. Interactive effects of water limitation and elevated temperature on the physiology, development and fitness of diverse accessions of Brachypodium distachyon. New Phytol. 2017, 214, 132-144. [CrossRef] [PubMed]

36. Ogawa, D.; Nakajima, N.; Tamaoki, M.; Aono, M.; Kubo, A.; Kamada, H.; Saji, H. The isochorismate pathway is negatively regulated by salicylic acid signaling in $\mathrm{O}_{3}$-exposed Arabidopsis. Planta 2007, 226, 1277-1285. [CrossRef]

37. Minocha, R.; Majumdar, R.; Minocha, S.C. Polyamines and abiotic stress in plants: A complex relationship. Front. Plant Sci. 2014, 5, 175. [CrossRef]

38. Podlesakova, K.; Ugena, L.; Spichal, L.; Dolezal, K.; De Diego, N. Phytohormones and polyamines regulate plant stress responses by altering GABA pathway. N. Biotechnol. 2019, 48, 53-65. [CrossRef]

39. Zhang, H.; Sonnewald, U. Differences and commonalities of plant responses to single and combined stresses. Plant J. 2017, 90, 839-855. [CrossRef]

40. Szczepaniec, A.; Finke, D. Plant-vector-Pathogen interactions in the context of drought stress. Front. Ecol. Evol. 2019, 7. [CrossRef]

41. Kassanis, B. Some effects of high temperature on the susceptibility of plants to the infection with viruses. Ann. Appl. Biol. 1952, 39, 358-369. [CrossRef]

42. Lebeurier, G.; Hirth, L. Effect of elevated temperatures on the development of two strains of tobacco mosaic virus. Virology 1966, 29, 385-395. [CrossRef]

43. Damsteegt, V.D. Maize streak virus: Effect of temperature on vector and virus. Phytopathology 1984, 74, 1317-1320. [CrossRef]

44. Syller, J. The influence of temperature on transmission of potato leaf roll virus by Myzus persicae Sulz. Potato Res. 1987, 30, 47-59. [CrossRef]

45. Tamada, T.; Harrison, B.D. Quantitative studies on the uptake and retention of potato leafroll virus by aphids in laboratory and field conditions. Ann. Appl. Biol. 1981, 98, 261-277. [CrossRef]

46. Anhalt, M.D.; Almeida, R.P. Effect of temperature, vector life stage, and plant access period on transmission of banana bunchy top virus to banana. Phytopathology 2008, 98, 743-748. [CrossRef]

47. Lowles, A.J.; Tatchell, G.M.; Harrington, R.; Clark, S.J. The effect of temperature and inoculation access period on the transmission of barley yellow dwarf virus by Rhopalosiphum padi (L.) and Sitobion avenae (F.). Ann. Appl. Biol. 1996, 128, 45-54. [CrossRef] 
48. Chung, B.M.; Canto, T.; Tenllado, F.; Choi, K.S.; Joa, J.H.; Ahn, J.J.; Kim, C.H.; Do, K.S. The Effects of High Temperature on Infection by Potato virus Y, Potato virus A, and Potato leafroll virus. Plant Pathol. J. 2016, 32, 321-328. [CrossRef]

49. Singh, M.N.; Paul Khurana, S.M.; Nagaich, B.B.; Agrawal, H.O. Environmental factors influencing aphid transmission of Potato virus Y and Potato leafroll virus. Potato Res. 1988, 31, 501-511. [CrossRef]

50. Smyrnioudis, I.N.; Harrington, R.; Katis, N.I.; Clark, S.J. The effect of drought stress and temperature on spread of barley yellow dwarf virus (BYDV). Agric. For. Entomol. 2000, 2, 161-167. [CrossRef]

51. Del Toro, F.J.; Choi, K.S.; Rakhshandehroo, F.; Aguilar, E.; Tenllado, F.; Canto, T. Ambient conditions of elevated temperature and $\mathrm{CO}_{2}$ levels are detrimental to the probabilities of transmission by insects of a Potato virus $\mathrm{Y}$ isolate and to its simulated prevalence in the environment. Virology 2019, 530, 1-10. [CrossRef]

52. Berges, S.E.; Vile, D.; Vazquez-Rovere, C.; Blanc, S.; Yvon, M.; Bediee, A.; Rolland, G.; Dauzat, M.; van Munster, M. Interactions Between Drought and Plant Genotype Change Epidemiological Traits of Cauliflower mosaic virus. Front. Plant Sci. 2018, 9, 703. [CrossRef]

53. Dader, B.; Fereres, A.; Moreno, A.; Trebicki, P. Elevated $\mathrm{CO}_{2}$ impacts bell pepper growth with consequences to Myzus persicae life history, feeding behaviour and virus transmission ability. Sci. Rep. 2016, 6, 19120. [CrossRef] [PubMed]

54. Van Munster, M.; Yvon, M.; Vile, D.; Dader, B.; Fereres, A.; Blanc, S. Water deficit enhances the transmission of plant viruses by insect vectors. PLoS ONE 2017, 12, e0174398. [CrossRef]

55. Yvon, M.; Vile, D.; Brault, V.; Blanc, S.; van Munster, M. Drought reduces transmission of Turnip yellows virus, an insect-vectored circulative virus. Virus Res. 2017, 241, 131-136. [CrossRef] [PubMed]

56. Penalver-Cruz, A.; Garzo, E.; Prieto-Ruiz, I.; Diaz-Carro, M.; Winters, A.; Moreno, A.; Fereres, A. Feeding behavior, life history, and virus transmission ability of Bemisia tabaci Mediterranean species (Hemiptera: Aleyrodidae) under elevated $\mathrm{CO}_{2}$. Insect Sci. 2019, 1-13. [CrossRef] [PubMed]

57. Nachappa, P.; Culkin, C.T.; Saya, P.M., II; Han, J.; Nalam, V.J. Water Stress Modulates Soybean Aphid Performance, Feeding Behavior, and Virus Transmission in Soybean. Front. Plant. Sci. 2016, 7, 552-567. [CrossRef]

58. Hong, Y.; Yi, T.; Tan, X.; Su, J.; Ge, F. Microbes affected the TYLCCNV transmission rate by the Q biotype whitefly under high $\mathrm{O}_{3}$. Sci. Rep. 2017, 7, 14412. [CrossRef]

59. Bosquee, E.; Boullis, A.; Bertaux, M.; Francis, F.; Verheggen, F.J. Dispersion of Myzus persicae and transmission of Potato virus $\mathrm{Y}$ under elevated $\mathrm{CO}_{2}$ atmosphere. Entomol. Exp. Appl. 2017, 166, 6. [CrossRef]

60. Trebicki, P.; Nancarrow, N.; Bosque-Perez, N.A.; Rodoni, B.; Aftab, M.; Freeman, A.; Yen, A.; Fitzgerald, G.J. Virus incidence in wheat increases under elevated $\mathrm{CO}_{2}$ : A 4-year study of yellow dwarf viruses from a free air carbon dioxide facility. Virus Res. 2017, 241, 137-144. [CrossRef]

61. Canto, T.; Aranda, M.A.; Fereres, A. Climate change effects on physiology and population processes of hosts and vectors that influence the spread of hemipteran-borne plant viruses. Glob. Chang. Biol. 2009, 15, 1884-1894. [CrossRef]

62. Xie,H.; Zhao, L.; Wang, W.; Wang, Z.; Ni, X.; Cai, W.; He, K. Changes in life history parameters of Rhopalosiphum maidis (Homoptera: Aphididae) under four different elevated temperature and $\mathrm{CO}_{2}$ combinations. J. Econ. Entomol. 2014, 107, 1411-1418. [CrossRef]

63. Guo, H.; Sun, Y.; Li, Y.; Tong, B.; Harris, M.; Zhu-Salzman, K.; Ge, F. Pea aphid promotes amino acid metabolism both in Medicago truncatula and bacteriocytes to favor aphid population growth under elevated $\mathrm{CO}_{2}$. Glob. Chang. Biol. 2013, 19, 3210-3223. [CrossRef] [PubMed]

64. Maino, J.L.; Kong, J.D.; Hoffmann, A.A.; Barton, M.G.; Kearney, M.R. Mechanistic models for predicting insect responses to climate change. Curr. Opin. Insect Sci. 2016, 17, 81-86. [CrossRef] [PubMed]

65. Lobo, J.M. The use of occurrence data to predict the effects of climate change on insects. Curr. Opin. Insect Sci. 2016, 17, 62-68. [CrossRef] [PubMed]

66. Jones, R.A.; Barbetti, M.J. Influence of climate change on plant disease infections and epidemics caused by viruses and bacteria. Plant Sci. Rev. 2012, 22, 1-31. [CrossRef]

67. Hughes, L.; Bazzaz, F.A. Effects of elevated $\mathrm{CO}_{2}$ on five plant-aphid interactions. Entomol. Exp. Appl. 2001, 99, 87-97. [CrossRef]

68. Wang, Q.; Eneji, A.E.; Kong, X.; Wang, K.; Dong, H. Salt Stress Effects on Secondary Metabolites of Cotton in Relation to Gene Expression Responsible for Aphid Development. PLoS ONE 2015, 10, e0129541. [CrossRef] 
69. Yan, H.; Guo, H.; Yuan, E.; Sun, Y.; Ge, F. Elevated $\mathrm{CO}_{2}$ and $\mathrm{O}_{3}$ alter the feeding efficiency of Acyrthosiphon pisum and Aphis craccivora via changes in foliar secondary metabolites. Sci. Rep. 2018, 8, 9964. [CrossRef]

70. Mewis, I.; Khan, M.A.; Glawischnig, E.; Schreiner, M.; Ulrichs, C. Water stress and aphid feeding differentially influence metabolite composition in Arabidopsis thaliana (L.). PLoS ONE 2012, 7, e48661. [CrossRef]

71. White, T.C.R. An index to measure weather-induced stress of trees associated with outbreaks of psyllids in Australia. Ecology 1969, 50, 905-910. [CrossRef]

72. Guo, H.; Sun, Y.; Peng, X.; Wang, Q.; Harris, M.; Ge, F. Up-regulation of abscisic acid signaling pathway facilitates aphid xylem absorption and osmoregulation under drought stress. J. Exp. Bot. 2016, 67, 681-693. [CrossRef]

73. Hsiao, T.C. Plant responses to water stress. Annu. Rev. Plant Physiol. 1973, 24, 519-569. [CrossRef]

74. Pompon, J.; Quiring, D.; Giordanengo, P.; Pelletier, Y. Role of xylem consumption on osmoregulation in Macrosiphum euphorbiae (Thomas). J. Insect Physiol. 2010, 56, 610-615. [CrossRef] [PubMed]

75. Pompon, J.; Quiring, D.; Goyer, C.; Giordanengo, P.; Pelletier, Y. A phloem-sap feeder mixes phloem and xylem sap to regulate osmotic potential. J. Insect Physiol. 2011, 57, 1317-1322. [CrossRef] [PubMed]

76. Daniels, M.; Bale, J.S.; Newbury, H.J.; Lind, R.J.; Pritchard, J. A sublethal dose of thiamethoxam causes a reduction in xylem feeding by the bird cherry-oat aphid (Rhopalosiphum padi), which is associated with dehydration and reduced performance. J. Insect Physiol. 2009, 55, 758-765. [CrossRef]

77. Trebicki, P.; Vandegeer, R.K.; Bosque-Perez, N.A.; Powell, K.S.; Dader, B.; Freeman, A.J.; Yen, A.L.; Fitzgerald, G.J.; Luck, J.E. Virus infection mediates the effects of elevated $\mathrm{CO}_{2}$ on plants and vectors. Sci. Rep. 2016, 6, 22785. [CrossRef]

78. Vassiliadis, S.; Plummer, K.M.; Powell, K.S.; Rochfort, S.J. Elevated $\mathrm{CO}_{2}$ and virus infection impacts wheat and aphid metabolism. Metabolomics 2018, 14, 1-13. [CrossRef]

79. Conroy, J.; Seneweera, S.; Basra, A.; Rogers, G.; Nissen-Wooller, B. Influence of rising atmospheric $\mathrm{CO}_{2}$ concentrations and temperature on growth, yield and grain quality of cereal crops. Funct. Plant Biol. 1994, 21, 741-759. [CrossRef]

80. Leakey, A.D.; Ainsworth, E.A.; Bernacchi, C.J.; Rogers, A.; Long, S.P.; Ort, D.R. Elevated $\mathrm{CO}_{2}$ effects on plant carbon, nitrogen, and water relations: Six important lessons from FACE. J. Exp. Bot. 2009, 60, 2859-2876. [CrossRef]

81. Kimball, B.A.; Kobayashi, K.; Bindi, M. responses of agricultural crops to free-air $\mathrm{CO}_{2}$ enrichment. Glob. Chang. Biol. 2002, 1, 429-443. [CrossRef]

82. Coviella, C.E.; Trumble, J.T. Effects of elevated atmospheric carbon dioxide on insect-plant interactions. Conserv. Biol. 1999, 13, 700-713. [CrossRef]

83. Newman, J.A. Climate change and cereal aphids: The relative effects of increasing $\mathrm{CO}_{2}$ and temperature on aphid population dynamics. Glob. Chang. Biol. 2004, 10, 11-16. [CrossRef]

84. Robinson, E.A.; Ryan, G.D.; Newman, J.A. A meta-analytical review of the effects of elevated $\mathrm{CO}_{2}$ on plant-arthropod interactions highlights the importance of interacting environmental and biological variables. New Phytol. 2012, 194, 321-336. [CrossRef] [PubMed]

85. Parizipour, M.H.G.; Ramazani, L.; Sardrood, B.P. Temperature affected transmission, symptom development and accumulation of Wheat dwarf virus. Plant Prot. Sci. 2018, 693, 222-234.

86. Suntio, T.; Makinen, K. Abiotic stress responses promote Potato virus A infection in Nicotiana benthamiana. Mol. Plant Pathol. 2012, 13, 775-784. [CrossRef]

87. Nancarrow, N.; Constable, F.E.; Finlay, K.J.; Freeman, A.J.; Rodoni, B.C.; Trebicki, P.; Vassiliadis, S.; Yen, A.L.; Luck, J.E. The effect of elevated temperature on Barley yellow dwarf virus-PAV in wheat. Virus Res. 2014, 186, 97-103. [CrossRef]

88. Aguilar, E.; Allende, L.; Del Toro, F.J.; Chung, B.N.; Canto, T.; Tenllado, F. Effects of Elevated $\mathrm{CO}_{2}$ and Temperature on Pathogenicity Determinants and Virulence of Potato virus X/Potyvirus-Associated Synergism. Mol. Plant Microbe Interact. 2015, 28, 1364-1373. [CrossRef]

89. Singh, A.; Permar, V.; Basavaraj; Tomar, B.S.; Praveen, S. Effect of Temperature on Symptoms Expression and Viral RNA Accumulation in Groundnut Bud Necrosis Virus Infected Vigna unguiculata. Iran. J. Biotechnol. 2018, 16, e1846. [CrossRef]

90. Trebicki, P.; Nancarrow, N.; Cole, E.; Bosque-Perez, N.A.; Constable, F.E.; Freeman, A.J.; Rodoni, B.; Yen, A.L.; Luck, J.E.; Fitzgerald, G.J. Virus disease in wheat predicted to increase with a changing climate. Glob. Chang. Biol. 2015, 21, 3511-3519. [CrossRef] 
91. Matros, A.; Amme, S.; Kettig, B.; Buck-Sorlin, G.H.; Sonnewald, U.; Mock, H.P. Growth at elevated $\mathrm{CO}_{2}$ concentrations leads to modified profiles of secondary metabolites in tobacco cv. SamsunNN and to increased resistance against infection with potato virus Y. Plant Cell Environ. 2006, 29, 126-137. [CrossRef]

92. Huang, L.; Ren, Q.; Sun, Y.; Ye, L.; Cao, H.; Ge, F. Lower incidence and severity of tomato virus in elevated $\mathrm{CO}_{2}$ is accompanied by modulated plant induced defence in tomato. Plant Biol. 2012, 14, 905-913. [CrossRef]

93. Zhang, S.; Li, X.; Sun, Z.; Shao, S.; Hu, L.; Ye, M.; Zhou, Y.; Xia, X.; Yu, J.; Shi, K. Antagonism between phytohormone signalling underlies the variation in disease susceptibility of tomato plants under elevated $\mathrm{CO}_{2}$. J. Exp. Bot. 2015, 66, 1951-1963. [CrossRef] [PubMed]

94. Leisner, S.M.; Turgeon, R.; Howell, S.H. Effects of host plant development and genetic determinants on the long-distance movement of cauliflower mosaic virus in Arabidopsis. Plant Cell 1993, 5, 191-202. [PubMed]

95. Szittya, G.; Silhavy, D.; Molnar, A.; Havelda, Z.; Lovas, A.; Lakatos, L.; Banfalvi, Z.; Burgyan, J. Low temperature inhibits RNA silencing-mediated defence by the control of siRNA generation. EMBO J. 2003, 22, 633-640. [CrossRef]

96. Tuttle, J.R.; Idris, A.M.; Brown, J.K.; Haigler, C.H.; Robertson, D. Geminivirus-mediated gene silencing from Cotton leaf crumple virus is enhanced by low temperature in cotton. Plant Physiol. 2008, 148, 41-50. [CrossRef] [PubMed]

97. Zhang, X.; Zhang, X.; Singh, J.; Li, D.; Qu, F. Temperature-dependent survival of Turnip crinkle virus-infected arabidopsis plants relies on an RNA silencing-based defense that requires dcl2, AGO2, and HEN1. J. Virol. 2012, 86, 6847-6854. [CrossRef]

98. Chung, B.N.; Choi, K.S.; Ahn, J.J.; Joa, J.H.; Do, K.S.; Park, K.S. Effects of Temperature on Systemic Infection and Symptom Expression of Turnip mosaic virus in Chinese cabbage (Brassica campestris). Plant Pathol. J. 2015, 31, 363-370. [CrossRef]

99. Jones, R.W.; Jackson, A.O.; Morris, T.J. Defective-interfering RNAs and elevated temperatures inhibit replication of tomato bushy stunt virus in inoculated protoplasts. Virology 1990, 176, 539-546. [CrossRef]

100. Obrepalska-Steplowska, A.; Renaut, J.; Planchon, S.; Przybylska, A.; Wieczorek, P.; Barylski, J.; Palukaitis, P. Effect of temperature on the pathogenesis, accumulation of viral and satellite RNAs and on plant proteome in peanut stunt virus and satellite RNA-infected plants. Front. Plant Sci. 2015, 6, 903. [CrossRef]

101. Del Toro, F.J.; Aguilar, E.; Hernandez-Walias, F.J.; Tenllado, F.; Chung, B.N.; Canto, T. High Temperature, High Ambient $\mathrm{CO}_{2}$ Affect the Interactions between Three Positive-Sense RNA Viruses and a Compatible Host Differentially, but not Their Silencing Suppression Efficiencies. PLoS ONE 2015, 10, e0136062. [CrossRef]

102. Kubota, K.; Ng, J.C. Lettuce chlorosis virus P23 Suppresses RNA Silencing and Induces Local Necrosis with Increased Severity at Raised Temperatures. Phytopathology 2016, 106, 653-662. [CrossRef]

103. Kiraly, L.; Cole, A.B.; Bourque, J.E.; Schoelz, J.E. Systemic cell death is elicited by the interaction of a single gene in Nicotiana clevelandii and gene VI of Cauliflower mosaic virus. Mol. Plant Microbe Interact. 1999, 12, 919-926. [CrossRef]

104. Lim, H.S.; Vaira, A.M.; Reinsel, M.D.; Bae, H.; Bailey, B.A.; Domier, L.L.; Hammond, J. Pathogenicity of Alternanthera mosaic virus is affected by determinants in RNA-dependent RNA polymerase and by reduced efficacy of silencing suppression in a movement-competent TGB1. J. Gen. Virol. 2010, 91, 277-287. [CrossRef] [PubMed]

105. Gutiérrez, S.; Michalakis, Y.; van Munster, M.; Blanc, S. Plant feeding by insect vectors can affect life cycle, population genetics and evolution of plant viruses. Funct. Ecol. 2013, 27, 610-623. [CrossRef]

106. Martiniere, A.; Bak, A.; Macia, J.L.; Lautredou, N.; Gargani, D.; Doumayrou, J.; Garzo, E.; Moreno, A.; Fereres, A.; Blanc, S.; et al. A virus responds instantly to the presence of the vector on the host and forms transmission morphs. eLife 2013, 2, e00183. [CrossRef] [PubMed]

107. Berthelot, E.; Ducousso, M.; Macia, J.L.; Bogaert, F.; Baecker, V.; Thebaud, G.; Gallet, R.; Yvon, M.; Blanc, S.; Khelifa, M.; et al. Turnip mosaic virus is a second example of a virus using transmission activation for plant-to-plant propagation by aphids. J. Virol. 2019, 93, e01822-e01918. [CrossRef]

108. Bak, A.; Cheung, A.L.; Yang, C.; Whitham, S.A.; Casteel, C.L. A viral protease relocalizes in the presence of the vector to promote vector performance. Nat. Commun. 2017, 8, 14493. [CrossRef]

109. Drucker, M.; Then, C. Transmission activation in non-circulative virus transmission: A general concept? Curr. Opin. Virol. 2015, 15, 63-68. [CrossRef]

110. Xu, P.; Chen, F.; Mannas, J.P.; Feldman, T.; Sumner, L.W.; Roossinck, M.J. Virus infection improves drought tolerance. New Phytol. 2008, 180, 911-921. [CrossRef] 
111. Westwood, J.H.; McCann, L.; Naish, M.; Dixon, H.; Murphy, A.M.; Stancombe, M.A.; Bennett, M.H.; Powell, G.; Webb, A.A.; Carr, J.P. A viral RNA silencing suppressor interferes with abscisic acid-mediated signalling and induces drought tolerance in Arabidopsis thaliana. Mol. Plant Pathol. 2013, 14, 158-170. [CrossRef]

112. Davis, T.S.; Bosque-Perez, N.A.; Foote, N.E.; Magney, T.; Eigenbrode, S.D. Environmentally dependent host-pathogen and vector-pathogen interactions in the Barley yellow dwarf virus pathosystem. J. Appl. Ecol. 2015, 52, 1392-1401. [CrossRef]

113. Aguilar, E.; Cutrona, C.; Del Toro, F.J.; Vallarino, J.G.; Osorio, S.; Perez-Bueno, M.L.; Baron, M.; Chung, B.N.; Canto, T.; Tenllado, F. Virulence determines beneficial trade-offs in the response of virus-infected plants to drought via induction of salicylic acid. Plant Cell Environ. 2017, 40, 2909-2930. [CrossRef] [PubMed]

114. Roossinck, M.J. The good viruses: Viral mutualistic symbioses. Nat. Rev. Microbiol. 2011, 9, 99-108. [CrossRef] [PubMed]

(C) 2020 by the author. Licensee MDPI, Basel, Switzerland. This article is an open access article distributed under the terms and conditions of the Creative Commons Attribution (CC BY) license (http://creativecommons.org/licenses/by/4.0/). 